\title{
Evaluating the Relationship Between Disease Severity and Serum Levels of Zinc, Calcium and Vitamin D in COVID-19 Patients
}

\section{Azam Jahangirimehr}

Shoushtar Faculty of Medical Sciences

\section{Azam Khalighi}

Shoushtar Faculty of Medical Science

Elham Abdolahi Shahvali ( $\square$ Abdolahi-e@shoushtarums.ac.ir)

Shoushtar Faculty of Medical Sciences https://orcid.org/0000-0003-3062-4896

\section{Mostafa Labibzadeh}

Shoushtar Faculty of Medical Science

\section{Nasrin Bahmanyari}

Shoushtar Faculty Of Medical Science

\section{Research article}

Keywords: Zinc, Vitamin D, Calcium, COVID-19, Disease severity.

Posted Date: April 28th, 2021

DOI: https://doi.org/10.21203/rs.3.rs-373248/v1

License: (c) (1) This work is licensed under a Creative Commons Attribution 4.0 International License. Read Full License 


\section{Abstract}

Introduction

SARS-CoV-2 is spreading rapidly worldwide these days so that it has infected people in many countries. It is a zoonotic virus and the cause of COVID-19 infectious pneumonia. The World Health Organization (WHO) declared it a pandemic on January 30,2020. Given that no standard treatment has been found for the new coronavirus so far, the present study seeks a way to reduce the incidence and severity of the disease along with health protocols. Some of the factors possibly effective in getting less infected by the SARS-CoV-2 are|taking medication supplements such as zinc, calcium, and vitamin D.

Materials and methods

This cross-sectional study was conducted from May 13 to May 30, 2020, on 93 COVID-19 patients admitted to Khatam Al-Anbia Hospital in Shushtar in southwestern Iran. Some patients' laboratory and clinical of were collected and analyzed using the Chi-squared test, the independent t-test, the KruskalWallis test, and the Spearman rank-order correlation coefficient by IBM SPSS Statistics 18.0 software.

Findings

The severity of the disease (40\%) of 37 patients was severe in pulmonary involvement. Serum levels of vitamin $D$ and zinc were lower than the average in all patients. Still, the severity of COVID-19 in patients was not significantly different from their zinc serum levels $(P=0.216)$. Serum vitamin $D$ was not significantly different $(P=0.102)$. The severity of COVID-19 in patients was significantly different according to serum calcium levels $(P=0.005)$. The lower the calcium level, the more severe the disease.

Conclusion

Given that the supplementation's effect in preventing COVID-19 has not been confirmed and no study has been published on the appropriate dose of these supplements in COVID-19, taking economically viable calcium-rich food sources, including dairy, is recommended.

\section{Introduction}

The SARS-CoV-2 is spreading rapidly worldwide, so that it has infected many countries. It is a zoonotic virus and the causative agent of COVID-19 pneumonia, which the WHO identified as a pandemic (1). The SARS-CoV-2 causes much lower mortality in patients than SARSr-CoV and MERSr-CoV, but has a significant potential for infection and transmission (2).

The WHO declared COVID-19 to be an epidemic because it is still spreading rapidly worldwide (3). Currently, the COVID-19 pandemic is one of Iran's most important health issues and the world's (4). The SARS-CoV-2 can be transmitted from human to human, and no effective treatment has been found so far. The most effective measures are prevention and control, finding suspicious patients and close contact, 
confirming patients and virus carriers, and preventing transmission through isolation, disinfection, and personal protection (2). Given that standard treatment for the COVID-19 has not yet been found (5), the present study seeks to reduce this disease's incidence and severity along with health protocols. A factor that may be effective in this way is taking supplements such as vitamin D, calcium, and zinc.

One of these elements is zinc, which is of particular importance due to the global epidemic of COVID-19. Zinc is considered a potential supportive treatment in treating COVID-19 infection due to its immunomodulatory effect and direct antiviral effect (6).

Zinc ion has been shown to directly inhibit SARS-CoV-1 RNA-dependent RNA polymerase activity from suppressing viral genomic RNA replication and preventing viral particle proliferation as a mechanism of action (7). Not only does it reduce the number of lymphocytes, but it also impairs the function of $T$ and $B$ lymphocytes $(8,9)$. Earlier studies demonstrated that a decreased zinc level favors this interaction of ACE2 with SARS-CoV-2 spike protein and likewise that an increased zinc level inhibits ACE2 expression resulting in reduced viral interaction (10).

Calcium is one of the most abundant minerals in the body, which makes up $39 \%$ of the body's total salts. Calcium plays a vital role in the immune system. It is very effective in nerve conduction, blood clotting, heart rate regulation, secretion of hormones and enzymes, and muscle contraction $(11,12)$. In addition to playing an essential role in strengthening bones and teeth, as a messenger, calcium also plays a significant role in cellular signaling pathways throughout the body $(13,14)$. Another element is vitamin $D$, which dates back hundreds of years to the link between vitamin $D$ deficiency and infectious diseases. Nineteenth-century studies found that sunlight was beneficial for patients suffering from tuberculosis (15).

Vitamin D plays an influential role in autoimmune diseases, cardiovascular disease, allergic and respiratory disorders $(16,17)$ This vitamin has immune regulating properties. Acting on the immune system inhibits the production of inflammatory cytokines and stimulates the production of antimicrobial peptides. This peptide plays an essential role in the body's defense against respiratory pathogens, as it both strengthens the immune response and clears bacteria from defense barriers and immune cells (18).Vitamin D deficiency also increases the risk of viral infections such as RSV-induced bronchiolitis and seasonal influenza (19). Numerous studies have shown an association between vitamin $D$ and respiratory asthma symptoms. This connection is probably through the effect of vitamin $D$ on immune system regulation (20).

This vitamin also plays an essential role in regulating the immune system through the interaction between 1 and 22-dihydroxyvitamin D and the vitamin D 1 receptor (VDR) (21).

In "A Review on the Role of Vitamin D in Asthma", Adite et al. (2009) found that it reduces respiratory infections, prevents asthma attacks, steroid resistance, reduces osteoporosis, and controls asthma. It becomes chronic and also plays an immune role in increasing the antimicrobial peptide and the production of interleukin-10 (22)Studies on the association of serum levels of vitamin D, calcium, and 
zinc with the severity of COVID-19 have yielded conflicting results. The results of some studies show that serum levels of vitamin D affect the COVID-19 severity, although studies in some areas do not confirm this relationship. This study intends to investigate the relationship between disease severity and serum levels of zinc, vitamin D, and calcium in COVID-19 patients.

\section{Materials And Methods}

\section{Subjects and data collection}

This cross-sectional study was conducted in 2020 to evaluate the serum levels of vitamin D, calcium, and zinc on the severity of the disease in patients with COVID-19, after obtaining the necessary permits from Shoushtar University of Medical Sciences. After receiving the required permission to collect data, the researcher went to the hospital and performed sampling by explaining the research objectives, obtaining patient satisfaction, and obtaining informed consent from the subjects.

This study was conducted from May 13 to May 30, 2020, on 93 COVID-19 patients admitted to Khatam al-Anbia Hospital in Shoushtar in southwestern Iran. For SARS-CoV-2 nucleic acid detection, the real-time reverse-transcriptase-polymerase-reaction (RT-PCR) was performed on nasopharyngeal and oropharyngeal swabs.

The subjects were selected via a purposive sampling method among COVID-19 patients admitted to Shoushtar Khatam Al-Anbia Hospital. Blood samples were taken from the patients by a hospital nurse (a project colleague) and sent to a private laboratory for more investigation.

Inclusion criteria were as follows: 1 . having an Iranian ethnicity and being a resident of Shoushtar city; 2 . being infected with COVID-19 based on PCR test; 3 . having the willingness to participate in the study; 4 . being over 15 years old, and 5 . being fasting during sampling.

Exclusion criteria were as follows: 1- living outside of Shoushtar city 2-having dissatisfaction to participate in the study; 3 - taking Vitamin D, calcium, and zinc supplements during the last six months before the study; 4- taking corticosteroid drugs, cholesterol-lowering drugs such as cholesterol and barbiturates and phenytoin (which they can reduce the serum levels of vitamin D, calcium and zinc in the body); 5 . having parathyroid disease, bone disease, chronic liver disease, kidney disease, and cancer; and 6 . having been treated with vitamin $D$, calcium and zinc.

Laboratory and clinical results

In this study, we measured serum levels of vitamin D, calcium, and zinc. Serum vitamin D levels were measured by ELISA (Enzyme-Linked Immunosorbent Assay). Serum levels of vitamin D were divided into $30 \mathrm{ng} / \mathrm{ml}-100 \mathrm{ng} / \mathrm{ml}$ as sufficient, $10 \mathrm{ng} / \mathrm{ml}-30 \mathrm{ng} / \mathrm{ml}$ as insufficient, and $<10 \mathrm{ng} / \mathrm{ml}$ as deficient. Calcium Arsenazo measured serum levels of calcium with a reference range of $8.6-10.3 \mathrm{mg} / \mathrm{dl}$. Serum levels of 
zinc were measured by Atomic Absorption Spectrophotometry (AAS) with a reference range of 70-127 $\mu \mathrm{g} / \mathrm{dl}$.

In this study, information such as age, gender, place of residence, calcium, zinc, and vitamin D supplementation, history of underlying diseases (diabetes, hypertension, heart disease, lung disease, hyperlipidemia); symptoms and possible complications of the disease (cough, shortness of breath). Stenosis, fever, muscle weakness, pain, nausea, vomiting, headache, dizziness, abdominal pain, seizures, chest pain, palpitations, blurred vision, diarrhea, restlessness, aggression, decreased sense of smell, etc.). Laboratory results such as serum levels of vitamin $D$, calcium, zinc, blood urea nitrogen (BUN), creatinine (cr), sodium (Na), potassium (K), white blood cell (WBC), red blood cell (RBC), hemoglobin (HB), hematocrit (HEMA), platelet (PLT), lymphocyte (Lym), neutrophils (Neut), Arterial Blood Gas Test (PH, PO2, $\mathrm{PCO} 2, \mathrm{HCO} 3)$, erythrocyte sedimentation rate (ESR), and blood sugar (BS) were recorded.

\section{Statistical analysis}

According to the research objectives, previous studies (55), and the parameter of respiratory problems in COVID-19 patients in the two normal serum calcium and low serum calcium groups, the subjects' proportions with respiratory problems in the two groups were $P 1=0.06$ and $P=0.016$. Also, given $\beta=0.9$, $a=0.05, d=0.08$ and using the sample volume ratio formula, the case group was estimated to consist of 93 subjects.

Blood test results, demographics, and clinical information were entered into IBM SPSS Statistics 18.0 software. Quantitative variables are reported as mean (average), standard deviation (mid-quarter range), minimum and maximum, and qualitative variables are reported as number (percentage). The Kolmogorov-Smirnov test was employed to confirm the normality of quantitative variables, the Spearman rank-order correlation coefficient to examine the relationship between quantitative variables, the independent t-test to compare means, the Kruskal-Wallis test to compare the levels of variables, the Chisquared test to compare qualitative variables in terms of number, and sequential regression to predict some factors affecting the severity of COVID-19. The significance level of the above tests is considered less than 0.05 .

\section{Findings}

The median [interquartile range, (IQR)] age of the 97 subjects was 51 (40-61). Fifty-two subjects (55.9\%) were female. The median [interquartile range, (IQR)] length of hospital stay was four days (3-5). Thirtyseven subjects (40\%) suffered from severe pulmonary involvement. 
Table 1

Comparison of underlying diseases and symptoms at different disease severity levels

\begin{tabular}{llll}
$\begin{array}{lll}\text { p-value } \\
\text { chi- } \\
\text { square }\end{array}$ & \multicolumn{2}{l}{ The disease severity } & \\
& $\mathrm{N}(\%)$ & \\
& SEVER & MEDIAN & LOW \\
& $\mathrm{N}=37$ & $\mathrm{~N}=30$ & $\mathrm{~N}=\mathbf{2 6}$
\end{tabular}

\begin{tabular}{|lllllll|}
\hline 0.06 & $10(66.7 \%)$ & $2(13.3 \%)$ & $3(20.0 \%)$ & $15(16.1 \%)$ & Diabetes & \multicolumn{1}{l}{$\begin{array}{l}\text { Underlying } \\
\text { diseases }\end{array}$} \\
\hline 0.292 & $6(60.0 \%)$ & $3(30.0 \%)$ & $1(10.0 \%)$ & $10(10.8 \%)$ & Hypertension & \\
\hline 0.249 & $1(12.5 \%)$ & $4(50.0 \%)$ & $3(37.5 \%)$ & $8(8.6 \%)$ & $\begin{array}{l}\text { Pulmonary } \\
\text { diseases }\end{array}$ \\
\hline 0.024 & $12(60.0 \%)$ & $7(35.0 \%)$ & $1(5.0 \%)$ & $20(21.5 \%)$ & $\begin{array}{l}\text { Cardiovascular } \\
\text { diseases }\end{array}$ \\
\hline 0.039 & $11(25.0 \%)$ & $16(36.4 \%)$ & $17(38.6 \%)$ & $44(47.3)$ & $\begin{array}{l}\text { No Underlying } \\
\text { diseases }\end{array}$ & Disease \\
\hline 0.196 & $12(44.4 \%)$ & $5(18.5 \%)$ & $10(37.0 \%)$ & $27(29.0 \%)$ & Fever \\
\hline 0.905 & $22(39.3 \%)$ & $19(33.9 \%)$ & $15(26.8 \%)$ & $56(60.2 \%)$ & Cough \\
\hline 0.849 & $16(42.1 \%)$ & $11(28.9 \%)$ & $11(28.9 \%)$ & $38(40.9 \%)$ & Dyspnea \\
\hline 0.515 & $6(33.3 \%)$ & $5(27.8 \%)$ & $7(38.9 \%)$ & $18(19.4 \%)$ & Muscle pain \\
\hline 0.647 & $3(27.3 \%)$ & $4(36.4 \%)$ & $4(36.4 \%)$ & $11(11.8 \%)$ & Headache \\
\hline 0.014 & $5(27.8 \%)$ & $3(16.7 \%)$ & $10(55.6 \%)$ & $18(19.4 \%)$ & Anorexia \\
\hline 0.523 & $4(33.3 \%)$ & $3(25.0 \%)$ & $5(41.7 \%)$ & $12(12.9 \%)$ & Fatigue \\
\hline 0.460 & $1(16.7 \%)$ & $3(50.0 \%)$ & $2(33.3 \%)$ & $6(6.5 \%)$ & Sore throat \\
\hline 0.486 & $2(25.0 \%)$ & $4(50.0 \%)$ & $2(25.0 \%)$ & $8(8.6 \%)$ & $\begin{array}{l}\text { Digestive } \\
\text { symptoms }\end{array}$ \\
\hline 0.117 & $0(0.0 \%)$ & $2(100.0 \%)$ & $0(0.0 \%)$ & $2(2.2 \%)$ & $\begin{array}{l}\text { Diminished sense } \\
\text { of smell }\end{array}$ \\
\hline
\end{tabular}

The Mean \pm SD serum level of vitamin $D$ in the subjects was $11.21 \pm 21.40$ with a variation range of $8-56$. Sixty-eight subjects (73\%) had vitamin D deficiency $(<30)$, and $25(27 \%)$ of them had normal serum levels of vitamin $D(30-100)$. 
The Mean \pm SD serum level of calcium in the subjects was $9.14 \pm 0.39$ with a variation range of 8.40 10.30. Thirty-nine subjects ( $42 \%$ ) had calcium deficiency $(<9)$, and $54(58 \%)$ of them had normal calcium levels (9-10.5).

The Mean \pm SD serum level of zinc in the subjects was $67.61 \pm 15.10$ with a variation range $41-112$. Forty-nine subjects (52.7\%) had zinc deficiency $(<70)$, and $44(47.3 \%)$ of them had normal serum levels of zinc (70-114).

Serum vitamin $D$ levels were not statistically significant between the male and female subjects $(P=$ 0.182); however, serum levels of vitamin $D$ were higher in male than female subjects. Serum levels of calcium were not significantly different between the male and female subjects $(P=0.059)$, but in the female subjects, serum calcium levels were lower than the male subjects. Serum zinc levels were not significantly different between the male and female subjects $(P=0.591)$. The disease's severity was higher in the male than female subjects $(P=0.009)$ (See Table 2$)$.

Table (2): Comparison of serum levels of vitamin D, calcium, zinc, and disease severity between men and women

\begin{tabular}{|llll|}
\hline & Male & Female & p-value \\
& $\mathbf{N}=\mathbf{4 1}$ & $\mathbf{N}=\mathbf{5 2}$ & t-test \\
\hline ZINC & $66.65 \pm 16.15$ & $68.36 \pm 14.33$ & 0.591 \\
(normal:70-127 $\mu \mathrm{g} / \mathrm{dl}$ ) & & & \\
\hline $\begin{array}{l}\text { CALCIUM } \\
\text { 8.6-10.3 mg/dl) normal:) }\end{array}$ & $9.21 \pm 0.41$ & $9.05 \pm 0.35$ & 0.059 \\
\hline $\begin{array}{l}\text { VITAMIN D } \\
\text { (normal:30-100 ng/ml) }\end{array}$ & $22.95 \pm 11.20$ & $20.25 \pm 11.18$ & 0.182 \\
\hline Severity of the disease & $2.36 \pm 0.76$ & & \\
\hline
\end{tabular}

The severity of the disease in coronary arteries was not significantly different according to the serum level of vitamin $D(P=0.102)$. The COVID-19 severity in patients was significantly different according to serum calcium levels $(P=0.005)$. The lower the serum levels of calcium, the more severe the disease. The severity of the COVID-19 was not significantly different in the subjects in terms of their serum levels of zinc $(P=0.216)$. There was a statistically significant and direct relationship between the severity of the disease with the age of patients $(P<0.001)$ and length of hospital stay $(P=0.026)$. With increasing age, the disease severity increases. Also, with increasing the disease severity, hospitalization prolongs. There was a statistically significant and direct relationship between BS and disease severity $(P=0.007)$. The higher the blood sugar level is, the more severe the disease is. People with more severe diseases had higher blood ESR levels $(P=0.048)$ (See Tables 3\&4). 
Table (3): Comparison of some demographics, serum levels of vitamin D, calcium, and zinc, and laboratory results at different levels of the disease severity 


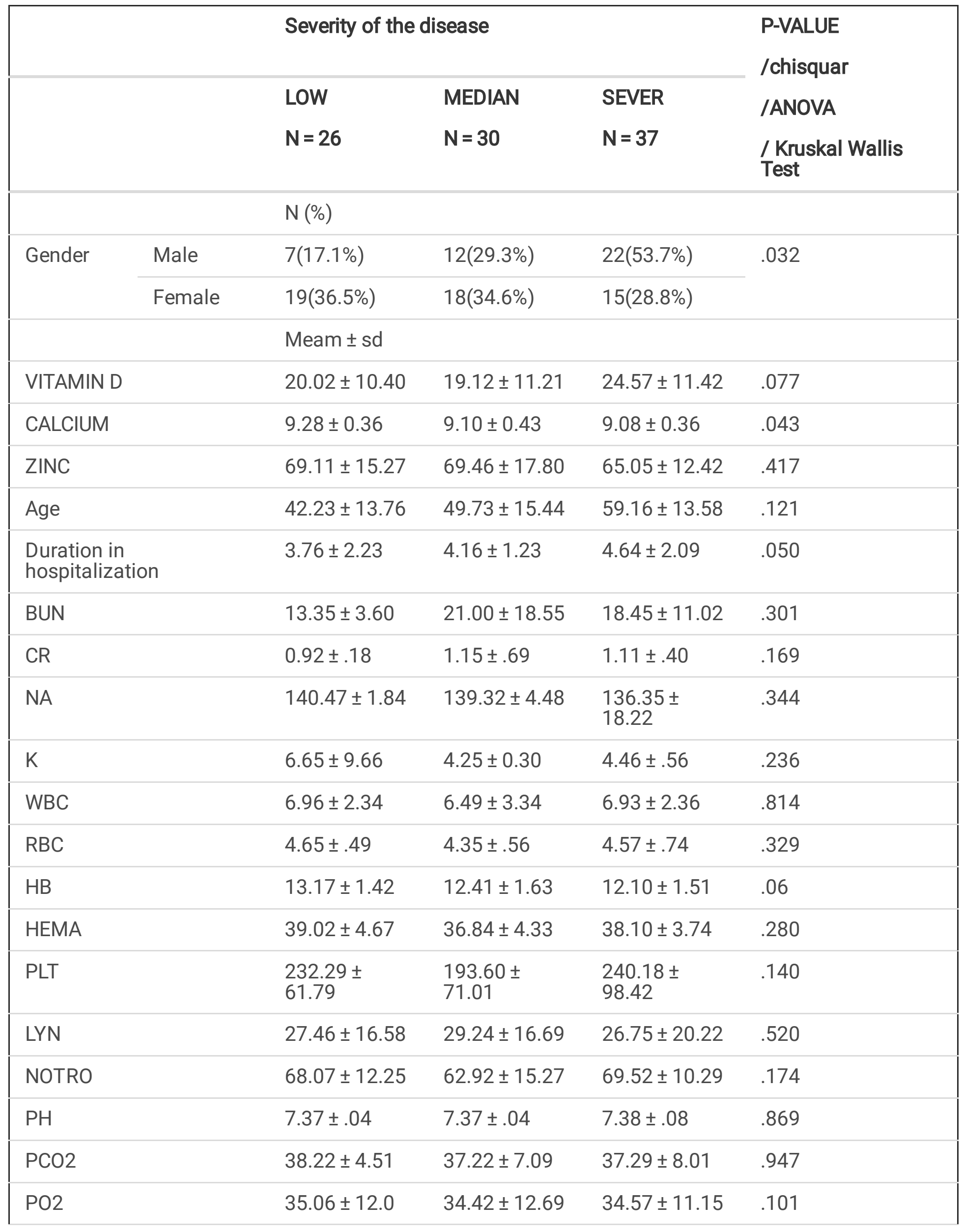




\begin{tabular}{|c|c|c|c|c|}
\hline & \multicolumn{3}{|c|}{ Severity of the disease } & \multirow{3}{*}{$\begin{array}{l}\text { P-VALUE } \\
\text { /chisquar } \\
\text { /ANOVA } \\
\text { / Kruskal Wallis } \\
\text { Test }\end{array}$} \\
\hline & LOW & MEDIAN & SEVER & \\
\hline & $N=26$ & $N=30$ & $N=37$ & \\
\hline $\mathrm{HCO} 3$ & $21.55 \pm 0.67$ & $21.66 \pm 2.56$ & $22.61 \pm 2.91$ & .554 \\
\hline ESR & $33.89 \pm 17.75$ & $22.25 \pm 12.10$ & $47.00 \pm 29.24$ & .048 \\
\hline BS & $\begin{array}{l}105.56 \pm \\
36.47\end{array}$ & $140.94 \pm 78.5$ & $\begin{array}{l}173.18 \pm \\
86.67\end{array}$ & .028 \\
\hline
\end{tabular}

Note:( Blood Urea Nitrogen(BUN), creatinine(cr), Sodium(Na), Potassium(K), WHITE BLOOD CELL(WBC), RED BLOOD CELL(RBC), HEMOGLOBIN( HB ), HEMATOCRIT(HEMA), PLATELET(PLT), LYMPHOCYTE(Lym), neutrophils(Neut), Arterial Blood Gas Test(PH,PO2,PCO2, HCO3), Erythrocyte sedimentation rate(ESR), Blood Sugar(BS).

Table (4): Investigation of the relationship between some demographics, serum levels of vitamin D, calcium, and zinc, and laboratory results at different disease severity levels 


\begin{tabular}{|c|c|c|}
\hline & Severity of the disease & P-VALUE \\
\hline & Spearman's rho & \\
\hline VITAMIN D & .175 & .102 \\
\hline CALCIUM & -.292 & .005 \\
\hline ZINC & -.129 & .216 \\
\hline Age & .457 & .000 \\
\hline BUN & .090 & .390 \\
\hline CR & .179 & .085 \\
\hline NA & -.052 & .622 \\
\hline K & .025 & .813 \\
\hline WBC & .037 & .757 \\
\hline RBC & -.052 & .666 \\
\hline $\mathrm{HB}$ & -.249 & .034 \\
\hline HEMA & -.012 & .919 \\
\hline PLT & .021 & .864 \\
\hline LYN & -.109 & .378 \\
\hline NOTRO & .058 & .640 \\
\hline $\mathrm{PH}$ & .227 & .246 \\
\hline $\mathrm{PCO} 2$ & -.081 & .681 \\
\hline PO2 & .329 & .088 \\
\hline $\mathrm{HCO} 3$ & .260 & .212 \\
\hline ESR & .213 & .235 \\
\hline BS & .360 & .007 \\
\hline
\end{tabular}

The rank regression was employed to examine the effect of other independent variables on the dependent variable. First, all the independent variables were entered into the model one by one. Each independent variable that had a significance level lower than 0.2 was entered into the final model. Of all the independent variables, only the variables vit.d, calcium, age, hemoglobin, blood sugar had a single effect on the dependent variable (the subjects' severity of pulmonary involvement). The other variables were also entered into the model. Based on the logit $=\log (x /(1-x))$ link function, the model was valid $(-2$ LogLikelihood $=159.418$, Chi-Square $=35.29, \mathrm{df}=8$, sig. $<0.001)$. The independent variables entered in the model can explain and predict $37 \%$ of the dependent variable variation (Nagelkerke $=0.369$ ). Variables 
such as blood glucose and age have significant and direct effects, and calcium and hemoglobin variables have significant and indirect effects on the subjects' pulmonary involvement severity.

Table (5): Estimation of independent variables on disease severity by sequential regression

\begin{tabular}{|c|c|c|c|c|c|c|c|c|}
\hline & & \multirow[t]{2}{*}{ Estimate } & \multirow[t]{2}{*}{$\begin{array}{l}\text { Std. } \\
\text { Error }\end{array}$} & \multirow[t]{2}{*}{ Wald } & \multirow[t]{2}{*}{ df } & \multirow[t]{2}{*}{ Sig. } & \multicolumn{2}{|c|}{$\begin{array}{l}95 \% \text { Confidence } \\
\text { Interval }\end{array}$} \\
\hline & & & & & & & $\begin{array}{l}\text { Lower } \\
\text { Bound }\end{array}$ & $\begin{array}{l}\text { Upper } \\
\text { Bound }\end{array}$ \\
\hline \multirow[t]{2}{*}{ Threshold } & [Severity = low] & -12.930 & 5.898 & 4.806 & 1 & .028 & -24.490 & -1.370 \\
\hline & $\begin{array}{l}\text { [Severity = } \\
\text { Median] }\end{array}$ & -10.892 & 5.847 & 3.470 & 1 & .063 & -22.353 & .569 \\
\hline \multirow[t]{9}{*}{ Location } & AGE & .050 & .016 & 9.837 & 1 & .002 & .019 & .082 \\
\hline & Vitamin D & .024 & .021 & 1.291 & 1 & .256 & -.017 & .065 \\
\hline & Calcium & -1.253 & .580 & 4.662 & 1 & .031 & -2.390 & -.116 \\
\hline & CR & -1.193 & .638 & 3.493 & 1 & .062 & -2.444 & .058 \\
\hline & $\mathrm{HB}$ & -.472 & .181 & 6.776 & 1 & .009 & -.828 & -.117 \\
\hline & BS & .011 & .004 & 3.775 & 1 & .048 & -0.00007 & .016 \\
\hline & P02 & .065 & .040 & 2.713 & 1 & .100 & -.012 & .143 \\
\hline & [sex = male] & 1.072 & .528 & 4.120 & 1 & .042 & .037 & 2.107 \\
\hline & [sex = female] & $0^{\mathrm{a}}$ & & & 0 & & & \\
\hline
\end{tabular}

Link function: Logit.

a. This parameter is set to zero because it is redundant.

\section{Discussion}

This study aimed to investigate the relationship between disease severity and serum levels of zinc, calcium, and vitamin D in COVID-19 patients. The findings show that serum levels of vitamin D and zinc did not affect the COVID-19 severity, given that serum levels are both lower than normal. However, serum calcium levels have a significant and direct effect on disease severity and may help predict the risk of more severe disease in COVID-19 patients.

Existing studies suggest that the nutrients zinc, calcium, and vitamin D may play a role in the course and severity of COVID-19 disease. However, based on SARS and other viral infections, the present research observations and results suggest nutritional supplements increase host resistance to RNA viral infections, including severe COVID-19. In this study, the severity of the disease in 37 patients (40\%) was associated 
with their pulmonary involvement. In Cao X et al. (2020), most COVID-19 patients showed mild to moderate symptoms, but approximately $15 \%$ suffered from severe pneumonia (23).

Moreover, Huang (2020) indicated that the disease's severity resulted in mortality (24).The present study showed that serum levels of zinc in all three groups were lower than normal. Still, the severity of the disease in the COVID-19 patients did not differ significantly according to their zinc serum levels. Yao et al. (2021) did not observe hospital survival time and disease severity (25).In an RCT study, Bansal et al. (2011) concluded that zinc supplementation does not affect severe and very severe pneumonia (26).However, Wessels et al. (2020) stated that zinc supplements are associated with shortening symptoms, reduced disease severity, and, most importantly, reduced morbidity and mortality in COVID-19 patients (27).

In the present study, serum levels of vitamin D were lower than normal in all three groups. Still, there was no significant difference in the COVID-19 severity concerning serum levels of vitamin $D(P=.014)$. At the same time, in "Assessing Vitamin D Deficiency in Asthmatic Children and Its Effect on Asthma Severity", Sadghi et al. (2017) found that there was a significant inverse relationship between serum levels of vitamin D and asthma severity (31). Amrein et al. (2014) stated that vitamin D3 deficiency is one of the causes of elevated plasma glucose and dyslipidemia.

Also, the modification of the plasma level of vitamin D3 can lead to decreased insulin resistance and the modification of plasma lipid patterns in patients with type 2 diabetes (28). Radujkovic et al. (2020) stated in their study that VITD levels did not differ significantly between disease severity groups (29). Hollams et al. (2011) showed that vitamin D deficiency is associated with asthma severity in children with the disease (19). In Brehm Childcare Asthma Management (CAMP) (2010) conducted on children with asthma in North America, low levels of vitamin D were directly associated with an increased risk of hospitalization (30). Barassi (2021) showed serum levels of vitamin D in patients with severe COVID-19, and more need for artificial ventilation was low (31)

In a randomized clinical trial study of COVID-19 hospitalized patients, Murai (2021) concluded that a high dose of vitamin D3, compared with placebo, did not significantly reduce hospital stays, and the use of high doses of vitamin D3 For the treatment of COVID-19 does not confirm moderate to severe (32). Among hospitalized patients with COVID-19, a single high dose of vitamin D3, compared with placebo, did not significantly reduce hospital length of stay. The findings do not support the use of vitamin D3 for the treatment of moderate to severe COVID-19.

The results also showed that the COVID-19 severity in patients was significantly different according to serum calcium levels $(P=0.037)$. The lower the calcium level, the more severe the disease. Recently, a high prevalence of hypocalcemia in COVID-19 patients was reported in several other articles. Sun (2020) stated that serum levels of calcium were associated with disease severity and prognosis in COVID-19 patients (33). 
The results of Yung et al. (2020) were consistent with those of the present study, as they reported that hypocalcemia might be an indicator for patients who are likely to have a severe disease (34).Also, the results of Sun et al. (2019) (35).and Luigi et al. (2020) (36). are consistent with those of the present study.

The results of our study showed that the severity of the disease was statistically significant and directly related to the age of patients $(P<0.001)$ and length of hospital stay $(P=.026)$. The severity of the disease increases with age. Lauc et al. State that the most critical predictor of COVID-19 disease severity is age (37). Huang I et al. (2020) also named old age as one of the causes of COVID-19 mortality (26). Targher et al. (2020) described older age as an independent variable with a higher risk of severe COVID-19 (38).In Lix et al. (2020), elderly patients were associated with severe COVID-19 (39).The present study results showed that the severity of the disease is higher in male than female subjects.

In "Clinical Period and Risk Factors for Adult Mortality Patients with COVID-19 in Wuhan, China", Fei Zhou et al. (2020) showed that most of the patients were male (34). Also, in the study of Targher et al. (2020), males were among the variables that were independently associated with a higher risk of severe COVID19 disease (38). In Lix et al. (2020), male patients were related to severe COVID-19 and death (39). While in Shamsizadeh (2019) (40), no statistically significant relationship was found between disease severity and gender.

Our study results showed that people whose disease was more severe had higher blood ESR levels. Deng SQ (2020) Most of the subjects had high ESR (2).

There was a statistically significant and direct relationship between BS and disease severity $(P=0.007)$. The higher a patient's blood sugar, the higher the severity of the disease. Targher et al. (2020) reported that diabetes is associated with an approximately 4-fold increase in the risk of severe COVID-19 (38). In Lix et al. (2020), patients with hypertension were associated with severe COVID-19 and higher mortality rates (39). Results of Deng (2020) (2), Zhang (2020) (44), Ruan (2020) (33), and Huang (2020) (24).also linked diabetes to disease severity.

\section{Conclusion}

Our findings show that serum levels of vitamin $D$ and zinc are lower than normal in all patients and have no effect on the COVID-19 severity. However, serum levels of calcium have a significant and direct effect on disease severity and may help predict the risk of more severe disease in COVID-19 patients. Because no study confirms the supplementation to help prevent COVID-19 and no research on the appropriate dose of the supplements in COVID-19 have not been published so far, the consumption of calcium-rich food sources, such as dairy, are economically viable, is recommended.

\section{Suggestions}

Because COVID-19 is a pandemic and there is currently no definitive cure for it, we must look for ways to prevent it. It is suggested that other studies with larger sample sizes in different parts of the world 
evaluate whether deficiency of these supplements is associated with an increase in the COVID-19 severity. Also, more immediate clinical trials are recommended to reach a definitive conclusion about taking vitamin D, Calcium, and zinc supplements to reduce the risk of getting infected by COVID-19, and its severity.

\section{Abbreviations}

Vit.D: Vitamin D;CA: calcium; RNA: RiboNucleic Acid; ACE2: Angiotensin-converting enzyme 2; CoV: Coronavirus; VDR: vitamin D 1 receptor; ELISA:Enzyme-Linked Immunosorbent Assay; AAS :Atomic Absorption Spectrophotometry ;SD: Standard deviation; IQR: Inter Quartile Range; WHO: World Health Organization ; BUN :Blood Urea Nitrogen; CR: Creatinine; Na :Sodium; K :Potassium; WBC :White Blood Cell; RBC :Red Blood Cell; HB: Hemoglobin; HEMA: Hematocrit; PLT: Platelet; LYM: Lymphocyte; Neut : Neutrophils; ABG: Arterial Blood Gas ; PH: Power of Hydrogen ; PO2: Partial Pressure of Oxygen; PCO2 :Partial Pressure of Carbon Dioxide, HCO3 Hydrogen Carbonate; ESR: Erythrocyte Sedimentation Rate; BS: Blood Sugar.

\section{Declarations}

\section{Acknowledgments}

We would like to thank all the participants in this study, as well as the material and spiritual efforts of the Vice Chancellor for Research of Shoushtar Faculty of Medical Sciences.

\section{Authors'contributions}

Conception and designof study: A. Jahangirimehr, A. Khalighi;

Acquisition of Data: A. Khalighi, N.Bahmanyari, M.Labibzadeh;

Analysis and/or interpretation of data: A. Jahangirimehr, E.Abdolahishahvali;

Drafting the Manuscript: A. Jahangirimehr, A. Khalighi, E.Abdolahishahvali;

Revising the manuscript critically for important intellectual content: A. Jahangirimehr, A. Khalighi, E.Abdolahishahvali.

\section{Funding}

Not applicable

\section{Availability of data and materials}

The datasets used during the current study are available from the corresponding author on reasonable request 


\section{Ethical Statement}

We herewith confirm that the trial protocol has been approved by the Central Ethics Commission of the Ministry of Healthcare of IRAN .This article is from a research project entitled Serum levels of vitamin D, calcium and zinc in people with coronavirus 19 in Shoushtar city with ethics code IR.SHOUSHTAR.REC.1399.017 .A written and oral informed consent was presented to each participant prior to participating in the study.

\section{Consent for publication}

This manuscript has not been published elsewhere by another journal.

\section{Competing interests}

The authors declared no competing interests.

\section{Author details}

${ }^{1}$ MSC of Biostatistics, Department of Public Health, Shoushtar Faculty of Medical Sciences, Shoushtar, Iran. ${ }^{2}$ Phd in Emergency Medicine, Khatam Al-Anbia Hospital, Shoushtar Faculty of Medical Sciences, Shoushtar, Iran. ${ }^{3}$ MSC of Nursing, Department of Nursing, Shoushtar Faculty of Medical Sciences, Shoushtar, Iran . ${ }^{4}$ Phd in laboratory Science, Shoushtar Faculty of Medical Sciences, Shoushtar, Iran. ${ }^{5}$ BS of Nursing, Khatam Al-Anbia Hospital, Shoushtar Faculty of Medical Sciences, Shoushtar, Iran.

\section{References}

1. Zhou P, Yang X-L, Wang X-G, Hu B, Zhang L, Zhang W, et al. Addendum: A pneumonia outbreak associated with a new coronavirus of probable bat origin. Nature. 2020:E6-E.

2. Deng S-Q, Peng H-J. Characteristics of and public health responses to the coronavirus disease 2019 outbreak in China. Journal of clinical medicine. 2020;9(2):575.

3. World Health Organization. Coronavirus disease (COVID-19) outbreak 2020 [Available from: (https://www.who.int).

4. Lipsitch M, Swerdlow DL, Finelli L. Defining the epidemiology of Covid-19-studies needed. New England journal of medicine. 2020;382(13):1194-6.

5. Huang C, Wang Y, Li X, Ren L, Zhao J, Hu Y, et al. Clinical features of patients infected with 2019 novel coronavirus in Wuhan, China. The lancet. 2020;395(10223):497-506.

6. Zhang L, Liu Y. Potential interventions for novel coronavirus in China: A systematic review. Journal of medical virology. 2020;92(5):479-90.

7. Yasui Y, Yasui H, Suzuki K, Saitou T, Yamamoto Y, Ishizaka T, et al. Analysis of the predictive factors for a critical illness of COVID-19 during treatment-relationship between serum zinc level and critical 
illness of COVID-19-. International Journal of Infectious Diseases. 2020;100:230-6.

8. Fraker P, Gershwin ME, Good R, Prasad A, editors. Interrelationships between zinc and immune function. Federation proceedings; 1986.

9. Fraker PJ, DePasquale-Jardieu P, Zwickl CM, Luecke RW. Regeneration of T-cell helper function in zinc-deficient adult mice. Proceedings of the National Academy of Sciences. 1978;75(11):5660-4.

10. Devaux CA, Rolain J-M, Raoult D. ACE2 receptor polymorphism: Susceptibility to SARS-CoV-2, hypertension, multi-organ failure, and COVID-19 disease outcome. Journal of Microbiology, Immunology and Infection. 2020.

11. Bailey RL, Dodd KW, Goldman JA, Gahche JJ, Dwyer JT, Moshfegh AJ, et al. Estimation of total usual calcium and vitamin D intakes in the United States. The Journal of nutrition. 2010;140(4):817-22.

12. JDG -MKH. Calcium intake of the U.S. population (What We Eat in America, NHANES 2009-2010). US DEPARTMENT OF AGRICULTURE. . 2014:1-8.

13. Gehlert S, Bloch W, Suhr F. Ca2+-dependent regulations and signaling in skeletal muscle: from electro-mechanical coupling to adaptation. International journal of molecular sciences. 2015;16(1):1066-95.

14. Wakabayashi T. Mechanism of the calcium-regulation of muscle contraction-In pursuit of its structural basis-. Proceedings of the Japan Academy, Series B. 2015;91(7):321-50.

15. Davies P, Brown R, Woodhead J. Serum concentrations of vitamin D metabolites in untreated tuberculosis. Thorax. 1985;40(3):187-90.

16. A. M. The effect of administration of oral single dose vitamin $D$ on outcome pediatric pneumonia in Boali hospital of Ardabil. Med J Ardabil Univ 2004:;10-3.

17. Kliegman RM SB, St Geme JW. . Nelson Textbook of Pediatric.19th ed. Elsevier Saunders PA. 2011.

18. Adams JS, Hewison M. Unexpected actions of vitamin D: new perspectives on the regulation of innate and adaptive immunity. Nature clinical practice Endocrinology \& metabolism. 2008;4(2):80-90.

19. Hollams E, Hart P, Holt B, Serralha M, Parsons F, De Klerk N, et al. Vitamin D and atopy and asthma phenotypes in children: a longitudinal cohort study. European Respiratory Journal. 2011;38(6):13207.

20. Paul G, Brehm JM, Alcorn JF, Holguín F, Aujla SJ, Celedón JC. Vitamin D and asthma. American journal of respiratory and critical care medicine. 2012;185(2):124-32.

21. Merewood A, Mehta SD, Grossman X, Chen TC, Mathieu JS, Holick MF, et al. Widespread vitamin D deficiency in urban Massachusetts newborns and their mothers. Pediatrics. 2010;125(4):640-7.

22. Ginde AA, Mansbach JM, Camargo CA. Vitamin D, respiratory infections, and asthma. Current allergy and asthma reports. 2009;9(1):81-7.

23. Cao X. COVID-19: immunopathology and its implications for therapy. Nature reviews immunology. 2020;20(5):269-70.

24. Huang I, Lim MA, Pranata R. Diabetes mellitus is associated with increased mortality and severity of disease in COVID-19 pneumonia-a systematic review, meta-analysis, and meta-regression. Diabetes 
\& Metabolic Syndrome: Clinical Research \& Reviews. 2020;14(4):395-403.

25. Yao JS, Paguio JA, Dee EC, Tan HC, Moulick A, Milazzo C, et al. The minimal effect of zinc on the survival of hospitalized patients with Covid-19: an observational study. Chest. 2020.

26. Bansal A, Parmar VR, Basu S, Kaur J, Jain S, Saha A, et al. Zinc supplementation in severe acute lower respiratory tract infection in children: a triple-blind randomized placebo controlled trial. The Indian Journal of Pediatrics. 2011;78(1):33-7.

27. Wessels I, Rolles B, Rink L. The potential impact of zinc supplementation on COVID-19 pathogenesis. Frontiers in immunology. 2020;11:1712.

28. Amrein K, Zajic P, Schnedl C, Waltensdorfer A, Fruhwald S, Holl A, et al. Vitamin D status and its association with season, hospital and sepsis mortality in critical illness. Critical care. 2014;18(2):113.

29. Radujkovic A, Hippchen T, Tiwari-Heckler S, Dreher S, Boxberger M, Merle U. Vitamin D deficiency and outcome of COVID-19 patients. Nutrients. 2020;12(9):2757.

30. Brehm JM, Schuemann B, Fuhlbrigge AL, Hollis BW, Strunk RC, Zeiger RS, et al. Serum vitamin D levels and severe asthma exacerbations in the Childhood Asthma Management Program study. Journal of Allergy and Clinical Immunology. 2010;126(1):52-8. e5.

31. Barassi A, Pezzilli R, Mondoni M, Rinaldo RF, Davì M, Cozzolino M, et al. Vitamin D in severe acute respiratory syndrome coronavirus 2 (SARS-CoV-2) patients with non-invasive ventilation support. Panminerva Medica. 2021.

32. Murai IH, Fernandes AL, Sales LP, Pinto AJ, Goessler KF, Duran CSC, et al. Effect of a Single High Dose of Vitamin D3 on Hospital Length of Stay in Patients With Moderate to Severe COVID-19: A Randomized Clinical Trial. Jama. 2021.

33. Ruan Q, Yang K, Wang W, Jiang L, Song J. Clinical predictors of mortality due to COVID-19 based on an analysis of data of 150 patients from Wuhan, China. Intensive care medicine. 2020;46(5):846-8.

34. Yang C, Ma X, Wu J, Han J, Zheng Z, Duan H, et al. Low serum calcium and phosphorus and their clinical performance in detecting COVID-19 patients. Journal of medical virology. 2021;93(3):163951.

35. Sun J-K, Zhang W-H, Zou L, Liu Y, Li J-J, Kan X-H, et al. Serum calcium as a biomarker of clinical severity and prognosis in patients with coronavirus disease 2019: a retrospective cross-sectional study. 2020.

36. Di Filippo L, Formenti AM, Rovere-Querini P, Carlucci M, Conte C, Ciceri F, et al. Hypocalcemia is highly prevalent and predicts hospitalization in patients with COVID-19. Endocrine. 2020;68(3):475-8.

37. Lauc G SD. Biomarkers of biological age as predictors of COVID-19 disease severity. Aging (Albany NY). . 2020;12(8):6490.

38. Targher G, Mantovani A, Wang X-B, Yan H-D, Sun Q-F, Pan K-H, et al. Patients with diabetes are at higher risk for severe illness from COVID-19. Diabetes \& metabolism. 2020;46(4):335. 
39. Li X, Xu S, Yu M, Wang K, Tao Y, Zhou Y, et al. Risk factors for severity and mortality in adult COVID19 inpatients in Wuhan. Journal of Allergy and Clinical Immunology. 2020;146(1):110-8.

40. Ahmad Shamsizadeh.Roya Nikfar MS, Tahereh Ziaei Kajbaf,Amir Saberi-Demneh,Reza Karbalaei. Assessment of serum 25(OH)D level in infants with bronchiolitis. Tehran UniversityMedical Journal. 2017;75(12):888-93. 